\title{
Model Pengembangan Usaha Ternak Sapi Perah Berdasarkan Faktor Aksesibilitas Sumber Daya
}

\author{
Model of Dairy Cattle Business Development Based on Resources Accessibility Factors
}

\author{
Amam $^{1,2}$, M. W. Jadmiko ${ }^{1}$, P. A. Harsita ${ }^{1}$, dan M. S. Poerwoko ${ }^{3}$ \\ 1) Program Studi Peternakan, Fakultas Pertanian, Universitas Jember \\ 2) Program Studi Agribisnis, Fakultas Pertanian, Universitas Jember \\ 3) Program Studi Agronomi, Fakultas Pertanian, Universitas Jember \\ Jalan Kalimantan No. 37 Kampus Tegalboto, Sumbersari, Jember, Jawa Timur 68121 \\ Corresponding e-mail : amam.faperta@unej.ac.id
}

\begin{abstract}
This research aims to find a model for developing dairy cattle business based on resources farmers' accessibility. The research was conducted at the Kelompok Usaha Bersama (KUB) Tirtasari Kresna Gemilang in Pujon District, Malang Regency, East Java Province. The research was conducted in October - December 2018. The research variables consisted of economycal resources $\left(\mathrm{X}_{1}\right)$, environmental resources $\left(\mathrm{X}_{2}\right)$, social resources $\left(\mathrm{X}_{3}\right)$, farmers' $\mathrm{HR}\left(\mathrm{Z}_{1}\right)$, and development of dairy cattle business $\left(\mathrm{Y}_{1}\right)$. Respondents was all KUB member dairy cattle farmers, namely 174 dairy cattle farmers. Data was analyzed by the SEM (Structural Equation Model) with SmartPLS 2.0 method. The results showed that the resources farmers' accesibility directly affected the development of dairy cattle business by $10.8 \%$, while the resources farmers' accessibility indirectly affected with farmers' HR for development of dairy cattle businesses by $34.1 \%$. The conclusion of the research shows that the resources farmers' accessibility plays an important role in the development of livestock farming business.
\end{abstract}

Keywords: resources, economycal, environmental, social, and human resources.

\begin{abstract}
ABSTRAK
Penelitian ini bertujuan untuk menemukan model pengembangan usaha ternak sapi perah berdasarkan aksesibilitas peternak terhadap sumber daya. Penelitian dilakukan pada Kelompok Usaha Bersama (KUB) Tirtasari Kresna Gemilang Kecamatan Pujon, Kabupaten Malang, Provinsi Jawa Timur. Penelitian dilaksanakan pada bulan Oktober - Desember 2018. Variabel penelitian terdiri dari sumber daya ekonomi $\left(\mathrm{X}_{1}\right)$, sumber daya lingkungan $\left(\mathrm{X}_{2}\right)$, sumber daya sosial $\left(\mathrm{X}_{3}\right)$, SDM peternak $\left(\mathrm{Z}_{1}\right)$, dan pengembangan usaha ternak sapi perah $\left(\mathrm{Y}_{1}\right)$. Responden adalah semua peternak sapi perah anggota KUB, yaitu sebanyak 174 peternak sapi perah. Analisis data menggunakan metode SEM (Structural Equation Model) dengan SmartPLS 2.0. Hasil penelitian menunjukkan bahwa aksesibilitas peternak terhadap sumber daya berpengaruh secara langsung terhadap pengembangan usaha ternak sapi perah sebesar $10.8 \%$, sedangkan aksesibilitas peternak terhadap sumber daya berpengaruh secara tidak langsung melalui SDM peternak terhadap pengembangan usaha ternak sapi perah sebesar $34.1 \%$. Kesimpulan dari penelitian menunjukkan bahwa aksesibilitas peternak terhadap sumber daya berperan penting terhadap pengembangan usaha ternak.
\end{abstract}

Kata kunci: sumber daya, ekonomi, lingkungan, sosial, dan SDM.

\section{PENDAHULUAN}

Kelompok Usaha Bersama (KUB) Tirtasari Kresna Gemilang merupakan salah satu kelembagaan peternak sapi perah yang terdapat di Kecamatan Pujon Kabupaten Malang Provinsi Jawa Timur. KUB Tirtasari Kresna Gemilang berdiri tahun 2017 dan sudah memiliki Badan Hukum Nomor 0010084-AH.01.07. Jumlah peternak yang tergabung dalam KUB Tirtasari Kresna Gemilang sebanyak 174 orang dengan produksi susu pada bulan November 2018 yang mencapai 76.079 liter.

Undang-undang Nomor 19 tahun 2013 tentang Perlindungan dan Pemberdayaan Petani merupakan salah satu dasar berdirinya KUB Tirtasari Kresna Gemilang, sehingga penguatan kelembagaan membutuhkan dukungan dari banyak pihak (Wahyuni, 2017). Kuatnya kelembagaan sangat 
bergantung pada Sumber Daya Manusia (SDM) yang ada di dalamnya. Riyadi (2012) menyebutkan bahwa salah satu upaya untuk meningkatkan daya saing yaitu faktor SDM dan teknologi, Susilowati et al. (2013) juga menambahkan bahwa aspek pengelolaan SDM terbukti berpengaruh positif secara langsung dan signifikan terhadap kinerja organisasi.

Peternak sapi perah yang tergabung di dalam KUB Tirtasari Kresna Gemilang mempunyai aksesibilitas sumber daya yang berbeda, terutama sumber daya ekonomi, sumber daya lingkungan, dan sumber daya sosial (Syukur et al., 2014) yang mana faktor-faktor sumber daya tersebut erat kaitannya dengan pengembangan usaha ternak sapi perah. Semakin tinggi akses peternak terhadap sumber daya, maka semakin besar peluang peternak untuk mengembangkan usaha ternaknya.

Sumber daya ekonomi merupakan sumber daya yang dapat diakses peternak sapi perah yang erat kaitannya dengan masalah perekonomian peternak. Jenis sumber daya ekonomi meliputi: pendidikan formal, pendidikan nonformal, tingkat keterlibatan tenaga kerja keluarga, status kesehatan keluarga, status konsumsi gizi keluarga, tingkat kenyamanan rumah tempat tinggal, kesempatan memanfaatkan waktu luang untuk rekreasi, dan tingkat kredibilitas peternak.

Sumber daya lingkungan merupakan sumber daya yang dapat diakses peternak sapi perah yang erat kaitannya dengan masalah lingkungan usaha ternak. Jenis sumber daya lingkungan meliputi: pencemaran udara, pencemaran tanah, pencemaran air, pencemaran suara, pemanfaatan limbah kotoran ternak untuk pupuk, dan pemanfaatan limbah pertanian untuk pakan ternak.

Sumber daya sosial merupakan sumber daya yang dapat diakses peternak sapi perah yang erat kaitannya dengan hubungan sosial peternak. Jenis sumber daya sosial meliputi: peranan peternak dalam organisasi masyarakat, hubungan kerjasama dengan peternak lain, hubungan dengan sesama peternak, hubungan dengan aparat desa, hubungan dengan petugas kesehatan ternak, hubungan dengan dinas peternakan, hubungan dengan perusahaan pakan, hubungan dengan tenaga penyuluh, hubungan dengan lembaga keuangan, hubungan dengan lembaga pemasaran susu.

SDM peternak sapi perah merupakan salah satu faktor yang sangat penting yang tidak bisa dilepaskan dari suatu organisasi atau kelembagaan peternak sapi perah. Berkembang atau tidaknya suatu kelembagaan sangat bergantung dari SDM yang ada di dalamnya. Hal tersebut karena SDM berfungsi sebagai penggerak, pemikir, dan perencana untuk mencapai tujuan organisasi atau kelembagaan peternak sapi perah. SDM peternak sapi perah meliputi: pengetahuan dan keterampilan dalam usaha ternak, status kesehatan peternak, motivasi peternak, dan kemampuan peternak dalam penggunaan bahasa sehari-hari.

Pengembangan usaha ternak sapi perah merupakan suatu keadaan mengenai peluang potensial yang disertai dukungan berbagai aspek sumber daya yang dimiliki peternak sapi perah. Pengembangan usaha ternak sapi perah meliputi: bertambahnya pendapatan, bertambahnya populasi ternak sapi perah yang dipelihara, bertambahnya tenaga kerja yang dibayar, dan bertambahnya kandang.

\section{Tujuan Penelitian}

Penelitian bertujuan untuk menemukan model pengembangan usaha ternak sapi perah di KUB Tirtasari Kresna Gemilang berdasarkan akses peternak terhadap sumber daya ekonomi, sumber daya lingkungan, dan sumber daya sosial.

\section{Hipotesis Penelitian}

Berdasarkan tujuan penelitian, maka hipotesis penelitian yaitu: 1) akses peternak terhadap sumber daya mempengaruhi SDM peternak, dan 2) akses peternak terhadap sumber daya mempengaruhi pengembangan usaha ternak sapi perah di KUB Tirtasari Kresna Gemilang. 


\section{MATERI DAN METODE}

\section{Lokasi dan Waktu Penelitian}

Penelitian dilakukan di Kelompok Usaha Bersama (KUB) Tirtasari Kresna Gemilang Kecamatan Pujon Kabupaten Malang Provinsi Jawa Timur. Penelitian dilakukan pada bulan Oktober hingga Desember 2018.

\section{Variabel Penelitian}

Penelitian terdiri dari 5 variabel utama dan 31 indikator. Variabel utama tersebut yaitu: a) sumber daya ekonomi, b) sumber daya lingkungan, c) sumber daya sosial, d) SDM peternak, dan e) pengembangan usaha ternak sapi perah.

\section{Populasi Penelitian}

Responden merupakan peternak sapi perah yang tergabung di dalam Kelompok Usaha Bersama (KUB) Tirtasari Kresna Gemilang, Kecamatan Pujon Kabupaten Malang Provinsi Jawa Timur. KUB mempunyai anggota sebanyak 174 peternak sapi perah, sehingga di dalam penelitian ini semua peternak anggota KUB dijadikan responden penelitian (total sampling).

Tabel 1. Variabel dan Indikator Penelitian

\begin{tabular}{lc}
\hline Sumber Daya Ekonomi $\left(\mathrm{X}_{1}\right)$ & Notasi \\
\hline pendidikan formal peternak & $\mathrm{X}_{1.1}$ \\
pendidikan nonformal peternak & $\mathrm{X}_{1.2}$ \\
tingkat keterlibatan tenaga kerja keluarga & $\mathrm{X}_{1.3}$ \\
status kesehatan keluarga & $\mathrm{X}_{1.4}$ \\
status konsumsi gizi keluarga & $\mathrm{X}_{1.5}$ \\
tingkat kenyamanan rumah tempat tinggal & $\mathrm{X}_{1.6}$ \\
kesempatan memanfaatkan waktu luang untuk rekreasi & $\mathrm{X}_{1.7}$ \\
tingkat kredibilitas peternak & $\mathrm{X}_{1.8}$ \\
\hline Sumber Daya Lingkungan $\left(\mathrm{X}_{2}\right)$ & $\mathrm{Notasi}$ \\
\hline tingkat pencemaran udara & $\mathrm{X}_{2.1}$ \\
tingkat pencemaran tanah & $\mathrm{X}_{2.2}$ \\
tingkat pencemaran air & $\mathrm{X}_{2.3}$ \\
tingkat pencemaran suara & $\mathrm{X}_{2.4}$ \\
pemanfaatan limbah kotoran ternak untuk pupuk & $\mathrm{X}_{2.5}$ \\
pemanfaatan limbah pertanian untuk pakan ternak & $\mathrm{X}_{2.6}$ \\
\hline Sumber Daya Sosial $\left(\mathrm{X}_{3}\right)$ & $\mathrm{Notasi}$ \\
\hline peranan peternak dalam organisasi masyarakat & $\mathrm{X}_{3.1}$ \\
hubungan kerjasama dengan peternak lain & $\mathrm{X}_{3.2}$ \\
hubungan dengan aparat desa & $\mathrm{X}_{3.3}$ \\
hubungan dengan petugas kesehatan ternak & $\mathrm{X}_{3.4}$ \\
hubungan dengan dinas kesehatan & $\mathrm{X}_{3.5}$ \\
hubungan dengan perusahaan pakan ternak & $\mathrm{X}_{3.6}$ \\
hubungan dengan tenaga penyuluh & $\mathrm{X}_{3.7}$ \\
hubungan dengan lembaga keuangan & $\mathrm{X}_{3.8}$ \\
hubungan dengan lembaga/perusahaan pemasaran susu & $\mathrm{X}_{3.9}$ \\
\hline SDM Peternak ( $\mathrm{Z}_{1}$ ) & $\mathrm{Notasi}$ \\
\hline pengetahuan dan keterampilan dalam usaha ternak & $\mathrm{Z}_{1.1}$ \\
status kesehatan peternak & $\mathrm{Z}_{1.2}$ \\
motivasi peternak & $\mathrm{Z}_{1.3}$ \\
kemampuan peternak dalam penggunaan bahasa sehari-hari & $\mathrm{Z}_{1.4}$ \\
\hline Pengembangan Usaha Ternak Sapi Perah (Y) & $\left.\mathrm{Notasi}_{1}\right)$ \\
\hline bertambahnya pendapatan & $\mathrm{Y}_{1.1}$ \\
bertambahnya populasi ternak sapi perah yang dipelihara & $\mathrm{Y}_{1.2}$ \\
bertambahnya tenaga kerja yang dibayar & $\mathrm{Y}_{1.3}$ \\
bertambahnya kandang & $\mathrm{Y}_{1.4}$ \\
\hline & \\
\hline
\end{tabular}




\section{Pengumpulan Data}

Data diperoleh secara langsung dari responden dengan menggunakan metode pengisian kuisioner berskala likert 1 sampai dengan 5, selain itu metode wawancara dan observasi untuk pengamatan langsung juga dilakukan untuk mendapatkan informasi tambahan dari responden.

\section{Analisis Data}

Analisis data dilakukan dengan metode Structural Equation Model (SEM) dengan menggunakan SmartPLS 2.0. Hasil analisis tersebut digunakan untuk menjawab hipotesis. SmartPLS 2.0 bermanfaat untuk menemukan teori baru atau memperkuat teori yang lemah (Wiyono, 2011).

\section{HASIL DAN PEMBAHASAN}

\section{Uji Indikator}

Indikator yang mendukung variabel utama dalam penelitian ini diuji terlebih dahulu dengan menggunakan SmartPLS 2.0. Indikator yang dinyatakan valid dan memenuhi syarat yaitu indikator yang mempunyai nilai outer loading $>0.500$. Hasil uji indikator tersebut yaitu:

Tabel 2. Nilai Outer Loading

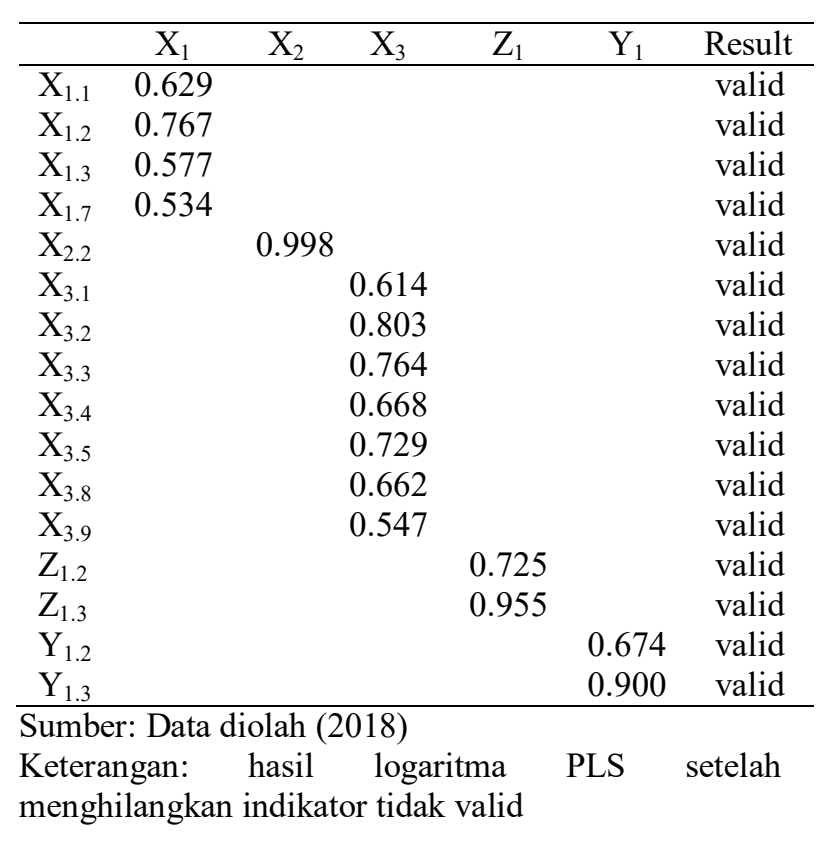

Hasil uji indikator menunjukkan bahwa peternak sapi perah di KUB Tirtasari Kresna Gemilang mempunyai akses terhadap sumber daya ekonomi yang terdiri dari: pendidikan formal peternak $\left(\mathrm{X}_{1.1}\right)$, pendidikan nonformal peternak $\left(\mathrm{X}_{1.2}\right)$, tingkat keterlibatan tenaga kerja keluarga $\left(\mathrm{X}_{1.3}\right)$, dan kesempatan memanfaatkan waktu luang untuk rekreasi $\left(\mathrm{X}_{1.7}\right)$. Peternak sapi perah di KUB Tirtasari Kresna Gemilang mempunyai akses terhadap sumber daya lingkungan berupa tingkat pencemaran tanah $\left(\mathrm{X}_{2.2}\right)$. Peternak sapi perah di KUB Tirtasari Kresna Gemilang mempunyai akses terhadap sumber daya sosial yang terdiri dari: peranan peternak dalam organisasi masyarakat $\left(\mathrm{X}_{3.1}\right)$, hubungan kerjasama dengan peternak lain $\left(\mathrm{X}_{3.2}\right)$, hubungan dengan aparat desa $\left(\mathrm{X}_{3.3}\right)$, hubungan dengan petugas kesehatan ternak $\left(\mathrm{X}_{3.4}\right)$, hubungan dengan dinas peternakan $\left(\mathrm{X}_{3.5}\right)$, hubungan dengan lembaga keuangan $\left(\mathrm{X}_{3.8}\right)$, dan hubungan dengan lembaga/perusahaan pemasaran susu $\left(\mathrm{X}_{3.9}\right)$.

Hasil uji indikator menunjukkan bahwa SDM peternak sapi perah terdiri dari kesehatan peternak $\left(Z_{1.2}\right)$ dan motivasi peternak $\left(Z_{1.3}\right)$, sedangkan indikator pengembangan usaha ternak sapi perah terdiri dari bertambahnya populasi sapi perah yang dipelihara $\left(\mathrm{Y}_{2.2}\right)$ dan bertambahnya tenaga kerja yang dibayar $\left(\mathrm{Y}_{2.3}\right)$.

\section{Uji Struktural}

Teknik analisis SEM dengan menggunakan SmartPLS 2.0 menghasilkan kriteria uji struktural berupa Composite Reliability (CR), R Square $\left(\mathrm{R}^{2}\right)$, dan nilai Cronbach's Alpha (CA). Hasil uji kriteria tersebut yaitu:

Tabel 3. Uji Struktural

\begin{tabular}{cccc}
\hline & $\mathrm{CR}$ & $\mathrm{R}^{2}$ & $\mathrm{CA}$ \\
\hline $\mathrm{X}_{1}$ & 0.723 & & 0.820 \\
$\mathrm{X}_{2}$ & 0.998 & & 0.998 \\
$\mathrm{X}_{3}$ & 0.861 & & 0.815 \\
$\mathrm{Z}_{1}$ & 0.756 & 0.107 & 0.993 \\
$\mathrm{Y}_{1}$ & 0.833 & 0.341 & 0.855 \\
\multicolumn{4}{l}{ Sumber: Data diolah (2018) }
\end{tabular}




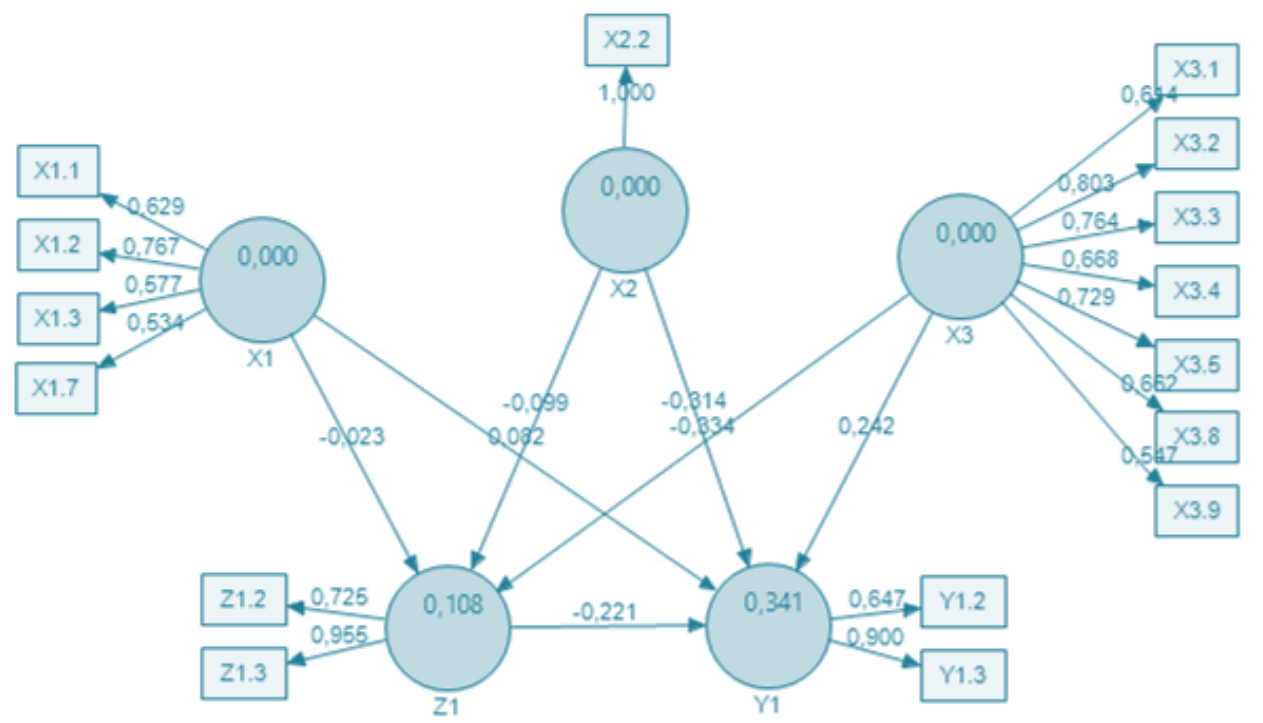

Gambar 1. Hasil Logaritma PLS

Uji struktural pada uji pengaruh atau uji hipotesis dilakukan sesudah melakukan uji indikator yang terdiri dari nilai koefisien determinasi $\left(\mathrm{R}^{2}\right)$, nilai t-statistik, dan nilai koefisien parameter. Hasil uji hipotesis tersebut yaitu:

Tabel 4. Uji Model

\begin{tabular}{|c|c|}
\hline Pengujian & Hasil Uji \\
\hline \multicolumn{2}{|l|}{ Koefisien Determinasi $\mathrm{R}^{2}$} \\
\hline SDM Peternak & 108 \\
\hline Pengembangan Usaha Sapi Perah & .341 \\
\hline \multicolumn{2}{|l|}{ T-statistik } \\
\hline $\mathrm{X}_{1} \rightarrow \mathrm{Z}_{1}$ & 0.126 \\
\hline $\mathrm{X}_{2} \rightarrow \mathrm{Z}_{1}$ & 0.720 \\
\hline $\mathrm{X}_{3} \rightarrow \mathrm{Z}_{1}$ & 2.350 \\
\hline $\mathrm{X}_{1} \rightarrow \mathrm{Y}_{1}$ & 0.783 \\
\hline $\mathrm{X}_{2} \rightarrow \mathrm{Y}_{1}$ & 1.904 \\
\hline $\mathrm{X}_{3} \rightarrow \mathrm{Y}_{1}$ & 3.306 \\
\hline $\mathrm{Z}_{1} \rightarrow \mathrm{Y}_{1}$ & 1.772 \\
\hline \multicolumn{2}{|l|}{ Koefisien Parameter } \\
\hline $\mathrm{X}_{1} \rightarrow \mathrm{Z}_{1}$ & -0.022 \\
\hline$X_{2} \rightarrow Z_{1}$ & -0.099 \\
\hline $\mathrm{X}_{3} \rightarrow \mathrm{Z}_{1}$ & -0.033 \\
\hline $\mathrm{X}_{1} \rightarrow \mathrm{Y}_{1}$ & 0.087 \\
\hline $\mathrm{X}_{2} \rightarrow \mathrm{Y}_{1}$ & -0.292 \\
\hline $\mathrm{X}_{3} \rightarrow \mathrm{Y}_{1}$ & 0.316 \\
\hline $\mathrm{Z}_{1} \rightarrow \mathrm{Y}_{1}$ & -0.221 \\
\hline
\end{tabular}

Sumber: Data diolah (2018)

Akses Peternak terhadap Sumber Daya dan Pengaruhnya terhadapSDM Peternak

SDM peternak sapi perah di KUB Tirtasari Kresna Gemilang dipengaruhi oleh akses peternak terhadap sumber daya sebesar $10.8 \%$. Sumber daya tersebut yaitu sumber daya ekonomi, sumber daya lingkungan, dan sumber daya sosial. Ellitan (2003) menyatakan bahwa ketersediaan sumber daya dapat berpengaruh positif ataupun negatif terhadap hubungan teknologi dan kinerja. Hal tersebut dapat diartikan bahwa ketersediaan sumber daya dapat menguatkan atau memperlemah pengaruh teknologi terhadap kinerja SDM.

Akses peternak terhadap sumber daya ekonomi memberikan pengaruh tetapi tidak signifikan terhadap SDM peternak sapi perah sebesar 0.126. Pengaruh tersebut menunjukkan hasil negatif sebesar -0.022 . Artinya, semakin rendah akses peternak terhadap sumber daya ekonomi maka semakin tinggi SDM peternak sapi perah di KUB Tirtasari Kresna Gemilang. Hal tersebut menunjukkan bahwa keterbatasan peternak terhadap sumber daya ekonomi dapat meningkatkan SDM peternak, khususnya motivasi peternak dan kesehatan peternak. Yudiarini (2014) menyebutkan bahwa akses peternak terhadap sumber daya ekonomi yang berkaitan dengan sarana dan prasarana transportasi dapat menjamin efisiensi usaha ternak yang lebih murah dan lebih mudah, sedangkan kondisi di lokasi penelitian menunjukkan bahwa di KUB Tirtasari Kresna Gemilang transportasi susu segar dikelola oleh kelompok peternak 
melalui kelembagaan, dan juga pakan ternak langsung diangkut ke lokasi kandangkandang sapi perah milik anggota, sehingga keterbatasan transportasi bukan menjadi kendala peternak sapi perah dalam memperoleh akses terhadap sumber daya ekonomi.

Akses peternak terhadap sumber daya lingkungan memberikan pengaruh tetapi tidak signifikan terhadap SDM peternak sapi perah sebesar 0.720. Pengaruh tersebut menunjukkan hasil negatif sebesar -0.099 . Artinya, semakin rendah akses peternak terhadap sumber daya lingkungan maka semakin tinggi SDM peternak sapi perah di KUB Tirtasari Kresna Gemilang. Kusnadi (2008) menyebutkan bahwa Sistem Integrasi Tanaman-Ternak (SITT) dalam sistem usaha pertanian merupakan ilmu rancang bangun dan rekayasa sumber daya tuntas. Artinya, suatu proses produksi biologis yang memanfaatkan sumber daya alam, sumber daya manusia, sumber daya finansial (modal), dan faktor manajemen yang jumlahnya terbatas. Hal tersebut menunjukkan bahwa SDM peternak di lokasi penelitian dikatakan tinggi jika peternak sudah menerapkan pemanfaatan kotoran ternak sebagai pupuk organik tanaman.

Akses peternak terhadap sumber daya sosial memberikan pengaruh yang sangat signifikan terhadap SDM peternak sapi perah sebesar 2.350. Pengaruh tersebut menunjukkan hasil negatif sebesar -0.033 . Artinya, semakin rendah akses peternak terhadap sumber daya sosial maka semakin tinggi SDM peternak sapi perah di KUB Tirtasari Kresna Gemilang. Nur (2004) mengatakan bahwa masalah-masalah sumber daya sosial yang berkaitan dengan subsistem pemasaran antara lain: a) sektor swasta menunjukkan persaingan usaha yang tidak sehat, b) sektor konsumen menunjukkan harga semakin naik sedangkan kualitas semakin turun, dan c) sektor kelompok tani menunjukkan selisih harga yang tinggi di tingkat petani dan di tingkat konsumen (sangat memarjinalkan petani), sehingga peran SDM bertujuan untuk memotivasi peternak baik secara langsung atau secara tidak langsung melalui kelembagaan peternak dengan melakukan pengolahan susu segar sebelum dipasarkan ke konsumen.Hal tersebut menunjukkan bahwa SDM peternak di lokasi penelitian dikatakan tinggi jika peternak mampu berperan di dalam organisasi masyarakat, mempunyai hubungan kerjasama yang baik dengan sesama peternak, aparat desa, tenaga kesehatan ternak, dinas peternakan, lembaga keuangan, dan lembaga pemasaran.

\section{Akses Peternak terhadap Sumber Daya dan Pengaruhnya terhadap Pengembangan Usaha Ternak Sapi Perah}

Pengembangan usaha ternak sapi perah di KUB Tirtasari Kresna Gemilang dipengaruhi oleh akses peternak terhadap sumber daya dan SDM peternak sebesar $34.1 \%$. Sumber daya tersebut yaitu sumber daya ekonomi, sumber daya lingkungan, dan sumber daya sosial. Perkembangan usaha peternakan harus didukung oleh berbagai sarana produksi atau sumber daya, salah satunya yaitu ketersediaan pakan ternak (Diwyanto et al., 2007). Hal tersebut menunjukkan bahwa akses peternak terhadap sumber daya dan sarana produksi sangat menunjang pengembangan usaha ternak.

Akses peternak terhadap sumber daya ekonomi memberikan pengaruh tetapi tidak signifikan terhadap pengembangan usaha ternak sapi perah sebesar 0.782. Pengaruh tersebut menunjukkan hasil positif sebesar 0.087 . Artinya, semakin besar akses peternak terhadap sumber daya ekonomi maka semakin besar peluang peternak untuk melakukan pengembangan usaha ternak sapi perah. Akses tersebut meliputi pendidikan formal peternak, pendidikan nonformal peternak, tingkat keterlibatan tenaga kerja keluarga, dan kesempatan peternak memanfaatkan waktu luang untuk rekreasi. Roessali et al. (2011) menyebutkan bahwa pengembangan usaha ternak dengan meningkatkan skala usaha ternak dipengaruhi secara positif signifikan oleh tingkat keterlibatan tenaga kerja keluarga dan harapan peternak, serta Riszqina et al. (2014) 
menambahkan bahwa keterampilan tenaga kerja dan motivasi berpengaruh nyata terhadap produktivitas usaha. Hal tersebut menunjukkan bahwa pengembangan usaha di lokasi penelitian diwujudkan oleh bertambahnya populasi ternak yang dipelihara dan bertambahnya tenaga kerja yang dibayar.

Akses peternak terhadap sumber daya lingkungan memberikan pengaruh signifikan terhadap pengembangan usaha ternak sapi perah sebesar 1.904. Pengaruh tersebut menunjukkan hasil negatif sebesar -0.292 . Artinya, semakin rendah akses peternak terhadap sumber daya lingkungan maka semakin besar peluang peternak untuk melakukan pengembangan usaha ternak sapi perah.Bamualim et al. (2015) menyatakan bahwa pemanfaatakan sumber daya lingkungan dengan pemberian pupuk organik dari kotoran ternak yang difortifikasi dengan pupuk kimia dapat meningkatkan hasil produktivitas tanaman sebesar 39-48\%, sehingga berpotensi untuk dilakukan pengembangan usaha melalui model SITT (Sistem Integrasi Tanaman-Ternak). Hal tersebut menunjukkan bahwa pengembangan usaha ternak di lokasi penelitian sangat memungkinkan untuk dilakukan jika peternak mampu memanfaatkan kotoran ternak sebagai pupuk tanaman.

Akses peternak terhadap sumber daya sosial memberikan pengaruh sangat signifikan terhadap pengembangan usaha ternak sapi perah sebesar 3.306. Pengaruh tersebut menunjukkan hasil positif sebesar 0.316. Artinya, semakin tinggi akses peternak terhadap sumber daya sosial maka semakin besar peluang peternak untuk melakukan pengembangan usaha ternak sapi perah. Limawandoyo dan Simanjutak (2013) menyebutkan bahwa salah satu rencana strategis pengelolaan SDM untuk meningkatkan produktivitas adalah dengan strategi model rekanan bisnis. Strategi tersebut mempunyai keunggulan yaitu kekuatan peternak atau kelembagaan ternak dimanfaatkan untuk menghalau ancaman dengan mengandalkan peluang. Hal tersebut menunjukkan bahwa pengembangan usaha ternak di lokasi penelitian sangat memungkinkan untuk dilakukan jika peternak mempunyai peranan dalam organisasi masyarakat serta mempunyai hubungan baik dengan sesama peternak sapi perah, aparat desa, petugas kesehatan ternak, dinas kesehatan, lembaga keuangan, dan lembaga pemasaran.

\section{Hubungan SDM Peternak dengan Pengembangan Usaha Ternak \\ SDM peternak di KUB Tirtasari} Kresna Gemilang memberikan pengaruh signifikan terhadap pengembangan usaha ternak sapi perah sebesar 1.772. Pengaruh tersebut menunjukkan hasil negatif sebesar 0.221. Artinya, semakin tinggi SDM peternak di KUB Tirtasari Kresna Gemilang maka semakin kecil peluang peternak untuk melakukan pengembangan usaha ternak sapi perah. Hal tersebut menunjukkan bahwa semakin sehat peternak dan masih mempunyai motivasi yang tinggi, peternak di KUB Tirtasari Kresna Gemilang lebih memilih untuk tidak melakukan pengembangan usaha ternak sapi perah. Motivasi juga berpengaruh terhadap komitmen (Prihantoro, 2012), semakin baik motivasi akan meningkatkan komitmen peternak untuk melakukan pengembangan usaha ternak. Penyebab utama peternak tidak ingin melakukan pengembangan usaha adalah tingginya risiko bisnis yang peternak rasakan. Semakin besar biaya investasi usaha ternak maka semakin besar risiko bisnis yang mungkin peternak terima, terlebih lagi peternak di KUB Tirtasari Kresna Gemilang sudah menyadari bahwa selama ini pihak kelembagaan KUB menjual susu segar ke Industri Pengolahan Susu (IPS) dalam satuan liter, padahal di tingkat perusahaan harga beli susu segar dikonversi dalam satuan kilogram.

Anantanyu (2011) menyatakan bahwa kelembagaan petani yang afektif diharapkan mampu memberikan kontribusi yang nyata dalam meningkatkan SDM, kemandirian, dan martabat petani, sehingga mampu memotivasi petani untuk berpartisipasi dalam kelembagaan. Upaya-upaya yang mungkin dilakukan oleh stakeholder antara lain: 
a) meningkatkan kapasistas penyuluh lapang, b) menggunakan pendekatan partisipatif yang berorientasi pada kebutuhan petani, dan c) memperkuat kelembagaan petani.Hal tersebut menunjukkan bahwa SDM peternak dapat mempengaruhi pengembangan usaha ternak. Rustandi dan Suhadji (2017) mengungkapkan bahwa keragaan fungsi kelompok tani atau kelembagaan petani yaitu sebagai kelas belajar sebesar 39,76\%, sebagai wahana kerjasama sesama petani sebesar $41,76 \%$, dan sebagai unit produksi sebesar $33,71 \%$. Hal tersebut menunjukkan bahwa pengembangan usaha ternak di lokasi penelitian sangat memungkinkan untuk dilakukan jika peternak sapi perah dalam kondisi sehat dan adanya motivasi dalam diri peternak.

\section{KESIMPULAN}

Akses peternak terhadap sumber daya mempengaruhi SDM peternak sapi perah sebesar $10.8 \%$. Akses peternak terhadap sumber daya dan SDM peternak mempengaruhi pengembangan usaha ternak sapi perah sebesar $34.1 \%$.

\section{SARAN}

1. Peternak anggota KUB Tirtasari Kresna Gemilang memiliki motivasi yang rendah untuk melakukan pengembangan usaha ternak sapi perah. Semakin besar biaya investasi usaha ternak, maka semakin besar risiko bisnis yang mungkin peternak terima. Hal tersebut membutuhkan perhatian dan dukungan dari pemerintah dan industri.

2. Peternak mengharapkan terbentuknya regulasi yang mengatur satuan konversi harga jual dan harga beli susu baik di tingkat peternak maupun di tingkat perusahaan.Selama ini harga jual susu segar di tingkat peternak dikonversi dalam satuan liter, sedangkan harga beli susu segar di tingkat perusahaan dikonversi dalam satuan kilogram. Hal tersebut menunjukkan ketimpangan yang menyebabkan peternak terus mengalami kerugian.

\section{DAFTAR PUSTAKA}

Anatanyu, S. 2011. Kelembagaan Petani: Peran dan Strategi Pengembangan Kapasitasnya. Jurnal SEPA. 7 (2): 102109.

Bamualim, A. M., Madarisa, F., Pendra, Y. Mawardi, E., dan Asmak. 2015. Jurnal Peternakan Indonesia. 17 (2): 83-93.

Diwyanto, K., Priyanti, A., dan Saptati, R. A. 2007. Prospek Pengembangan Usaha Peternakan Pola Integrasi. Sains Peternakan. 5 (2): 26-33.

Ellitan, L. 2003. Peran Sumber Daya dalam Meningkatkan Pengaruh Teknologi terhadap Produktivitas. Jurnal Manajemen \& Kewirausahaan. 5 (2): 155-170.

Kusnadi, U. 2008. Inovasi Teknologi Peternakan dalam Sistem Integrasi Tanaman-Ternak untuk Menunjang Swasembada Daging Sapi. Pengembangan Inovasi Pertanian. 1 (3): 189-205.

Limawandoyo, E. A. dan Simanjutak, A. 2013. Pengelolaan dan Pengembangan Sumber Daya Manusia pada PT Aneka Sejahtera Engineering. Jurnal Manajemen Bisnis Petra. 1 (2): 1-12.

Nur, P. 2004. Model Kelembagaan Pertanian dalam Rangka Mendukung Optimasi Produksi Padi. Falsafah Sains. 22 (6): 1-6.

Prihantoro, A. 2012. Peningkatan Kinerja Sumber Daya Manusia Melalui Motivasi, Disiplin, Lingkungan Kerja, dan Komitmen. Value Added. 8 (2): 78-98.

Riyadi. 2012. Faktor Sumber Daya Manusia yang Meningkatkan Kinerja Karyawan dan Perusahaan di Kalbar. Jurnal Eksos. 8 (2): 114-119.

Riszqina, Isbandi, E. Rianto, and S. I. Santoso. 2014. The Analysis of Factors Affecting The Performance in Benefits 
of Karapan (Racing) Cattle Business in Madura Island, East Java. JITAA. 39 (1): $65-72$.

Roessali, W., Masyhuri, S. Nurtini, Darwanto, D. H. 2011. Factors Influencing Farmers Decision to Increase Beef Cattle Business Scale in Central Java Province. JITAA. 36 (1): 27-35.

Rustandi, Y. dan Suhadji, R. 2017. Keragaan Evaluasi Fungsi Kelembagaan Kelompok Tani di Kecamatan Papar Kabupaten Kediri Jawa Timur. Agrica Ekstensia. 11 (2): 55-60.

Susilowati, Y., P. Hutagaol, P. Pasaribu, dan Djohar, S. 2013. Jurnal Manajemen Teknologi. Pengaruh Aspek Pengelolaan Sumber Daya Manusia terhadap Peningkatan Kinerja Organisasi di Industri Otomotif di Indonesia. Jurnal Manajemen Teknologi. 12 (1) : 1-19.
Syukur, S. H., Fanani, Z., Nugroho, B. A., and Antara, M. 2014. Empowerment of Livestock Farmer through Graduate Program to Build a Village on Dynamics of Beef Cattle Farmer Groups Level of Gaduhan Model (A Case Study in the District of Toli-toli, Central Sulawesi. Journal of Natural Science Research. 4 (2): 107-112.

Wahyuni, D. 2017. Penguatan Kelembagaan Petani Menuju Kesejahteraan Petani. Jurnal Kesejahteraan Sosial. 10 (17) : 9-12.

Wiyono, G. 2011. Merancang Penelitian Bisnis dengan Alat Analisis SPSS 17.0 \& Smart PLS 2.0. Penerbit: Unit Penerbit dan Percetakan STIM YKPN Yogyakarta.

Yudiarini, N. 2014. Perubahan Pertanian Subsisten Tradisional ke Pertanian Modern. DwijenAGRO. 2 (1): 1-8. 